\title{
Selection and Evaluation of Express Delivery Companies in the Environment
}

\author{
Dai Jinhui \\ Academic Affairs Office \\ Shengyang Aerospace University \\ Shengyang China \\ 54788451@qq.com
}

\begin{abstract}
- with the development of network technology and the emergence of electronic commerce, the express delivery industry has also been rapid development in E-Commerce Express showing new trends. Not only brought about by the emergence of electronic commerce in China is the rapid growth of social wealth and the convenience of people's lives. On the other hand, more logistics enterprises had a huge impact. E-commerce as a new mode of operation, not only changed the traditional industrial structure, and also present new challenges to the development of express industry. China's express delivery companies today and tomorrow also contains a huge space for development. The number of population-based online shopping is more and more consumers to express all aspects of quality of service requirements higher and higher, in order to find the present stage of online shopping the problems relating to express class, we have designed shopping online express delivery companies customer satisfaction survey to understand all aspects of the services of courier companies, expectations and overall satisfaction with, and then found that the problems of shopping online express delivery companies, and to suggest a resolution to seek the continued development of the logistics enterprises, improve customer satisfaction, while promoting the sound development of the consumer online shopping.
\end{abstract}

Keywords-express delivery companies; e-commerce; express choice; evaluation

\section{INTRODUCTION}

With the rapid development of global economy, competition on the market changes from minute to minute. Enterprises and individual consumers increasingly expect items required through electronic commerce platforms. China e-commerce development experienced a course from the initial 8848 platform to the $\mathrm{B}$ to $\mathrm{C}$ companies including Dangdang Net and $\mathrm{C}$ to $\mathrm{C}$ including posting companies and taobao.com. Logistics is the key factor to determine the success or failure of the above. Therefore, from the traditional goods transportation service, a rapid door-to-door service, namely, express service, happen. Without the express delivery service as support, the electronic commerce activities will not connect the virtual world with the real world. Therefore, express service plays a decisive role in electronic commerce. Express industry has a short history in China, but it is an industry with rapid development and great development potential. As one high value-added end of the logistics industry, it plays an important role in the world economic development stage. Therefore, electronic commerce must unite express and logistics enterprises for great development.

After more than 20 years of development, the express industry China has been growing rapidly into a greatly profiting modern service industry with a large market size and great potential. Although the express industry in China is developing rapidly with a great performance, the express service level has been criticized and express service has become one of the hot consumer complaints. In accordance with the relevant commitments for entering WTO, domestic express enterprises have directly faced the challenge from the international express companies. Therefore, improvement of express service performance and improvement of customer satisfaction and customer loyalty become the urgent issue.

\section{DEVELOPMENT STATUS OF EXPRESS ENTERPRISES IN CHINA}

\section{A. Development Process of Express in China}

International express and logistics industry rose from the end of 1960s in USA. The first express enterprise was founded in 1979. With China's policy of reform and opening up, the increasingly fierce market competition requires the society to provide more efficient and safe service delivery. Constantly improved traffic conditions and information management technology make the demand happen. The express industry in China was established. In 1980, Chinese Post Office started worldwide Express Mail Service (EMS), then international express giants also entered China through many ways including joint ventures, agency and other ways. The 1986 promulgation of Postal Law stipulates, "mailing of Mails and other articles with characteristics of mails should be specialized by post enterprises except those stipulated by the state council."

However, with further development of market economy, the postal enterprises are unable to meet the demand on express delivery of articles including customers clearing materials and samples, private express enterprises rise corresponding. In 1993, SF EXPRESS and ST Express were established respectively in the Pearl River Delta and Yangtze River Delta. In early 1994, Zhaijisong Express was established in Beijing. In December, 2005, China opened the logistics and express industry toward overseas in accordance with the WTO agreement. In September, 2007, in "Express Service" the postal industry standards 
were released, which provided standard service industry standards for the express industry. In July, 2008, Measures for Administration of Express Market was formally implemented. On October 1, 2009, Licensing and Management Approach on Express Transactions and the newly revised Postal Law were synchronously implemented. For the first time, the status of express enterprises was specified in law and this put forward the access threshold for the express industry.

Through more than 30 years of development, the express industry in China has formed a large-scale industry. In 2008, the registered express enterprises in China reached more than 5000 in quantity with 231,000 people working in the the whole industry. in 2009, express companies with a nationwide scale completed express of a total of 1.86 billion articles, an increase of $22.8 \%$ and with an accumulated business revenue totaled 47.9 billion yuan, a year-on-year growth of $17.3 \%$. in a whole year, the city, remote, international and Hong Kong-Taiwan-Macao express business reached incomes respectively accounting for $7.3 \%, 55.7 \%$ and $31.7 \%$ of all express income. The volumes of the business respectively account for $23.5 \%$, $70.4 \%$ and $6.1 \%$ of all express.

\section{B. Main Factors Restricting Development of Express Enterprises in China}

As without a unified and nationwide organization, the industry lacks self-disciplining and makes the domestic market competition very confused. At the same time, private express enterprises have a big gap with foreign giant in many aspects including business philosophy, service level and network structure. Express in China displays the phenomenon of scattered, small, weak, bad and many features. Mainly in the following aspects: : They are mainly displayed in the following,

\section{1) A large number of enterprises and a small scale}

At present, the private enterprises engaged in express industry in China total more thousands. According to a report by Shanghai Investigation Bureau, in 2009 private express enterprises in Shanghai totaled 467 and those with registered capital less than 200 thousand account for $90 \%$.According to the number of employees, those with less than 20 people accounted for $80 \%$ and only four companies respectively have more than 1000 personnel members. Shanghai is just the city where private express develops rapidly.

\section{2) Lack of Industry Standards}

Express industry is a relatively young industry, and it has not been included in the national economic statistics. It has no industry standard and it has confused operation.

3) Mechanization and Automation Degree is not High.

The private express enterprises in China is still very backward, they mainly make manual operation. In the private giants such as Zhaijisong Express, most logistics sections including packaging, sorting, loading, unloading and handling are manually operated.; There is a big gap between this and foreign capital giants.

\section{4) Capital Bottleneck}

In many factors in the private express enterprises, lack of funds and liquidity necessary for the normal development become one of the main restricting factors. Difficult financing is displayed in lack of effective normal performance. Most private enterprises takes free funds as main, and a few enterprises establishes channels including bank crediting, venture capital and privately collected funds. Secondly, bank crediting is difficult. "Private" and "express" the two new concept words increased loan difficulties. The financing guarantee system is not perfect. The bank mainly takes property as collateral. For the express industry, the characteristics of the real estate increase difficulty.

\section{5) Lack of Professional Talent}

The overall quality of private express practitioners is not high. In order to save the cost, hiring basically does not require a degree. Only some top management requires undergraduates. This leads to that business services, business and work efficiency of the enterprises are affected.

\section{Current Several Mainstream Online-Shopping Express Enterprises}

\section{1) $S F$ Express}

SF express, not to form, It is an enterprise administrated by its headquarters that the service levels in each region are unified. It is recognized in the industry. Its service and attitude are good. it has nationally unified telephone service with good supervision mechanism. Its express speed is high. The efficiency is the best. The shortcoming is that there are no outlets in remote places, and the costs are higher than other companies. Its speed and quality can be guaranteed.

\section{2) Post EMS}

The advantages of postal EMS are obvious: The stateowned holding, relying on the powerful national transportation system, network of many stores, and almost around the country (including rural).Operation is standard and it strength is assured. At least a person of the whole company comes out to solve problems (once such thing happened.). Post EMS freight vehicles may receive special care in some places (such as to some solutions, the private companies are unable to do so.). Post EMS reaches all corners of the world. You should consider it if you have foreign buyers. EMS also has shortcoming, namely, high cost, bureaucracy and low overall service quality.

3) ST Express

Although the company was founded in 1993, the company passed the ISO9001:2000 international quality management system certification in March 2004 and at present it has become one of the domestic private express enterprises with strong influence in the industry in China. At present, the main operating address of the company is 6186 Beiqing Road, Qingpu District, Shanghai City. The company headquarters have nearly 1000 people, and it set up more than 800 branch offices in all large cities in China. With absorption of more than 1100 stores, it has a total of more than 20 thousand personnel members.

\section{4) Yuantong Express}

Yuantong Express has also been recently criticized by the post office, but this does not affect its cooperation with many Taobao shops. Because Yuantong Express was established earlier. Although it is in joining form, the service level in each district may differ. It is a unit with many qualifications. There are many chain stores. If there is a problem in the aspect of express, you can at least claim to the Yuantong headquarters.

5) ZJS Express 
It is the largest domestic private express companies in China. With more than 500 chain stores in China, most stores are cooperative. It has about 100 stores belonging to itself. Advantages: Its speed is similar with that of EMS, and that of some areas are faster. Disadvantages: Because it has the joining system that uneven quality in each district happens and each store shall pay attention to this.

\section{6) Yunda Express}

After the merging, Yunda express grows rapidly in recent years and its quality and speed are slowly improving. But there are also disadvantages. The disadvantages are unbalanced development and complained stores.

\section{COMMENT AND ANALYSIS OF EXPRESS SELECTION}

\section{A. Competition Status On Express Market in China}

The express industry in China becomes a pearl in the industry of logistics with its rapid pace of development and good market prospects. On the broad market, the express industry is growing like a storm. There are many competitors. At present, there are three main forces in the battle for the domestic express market.

The first is the state-owned express companies with the most representative as EMS. In the early 1990's, EMS still monopolized the Chinese domestic and international express markets. But at the end of 2004, Sinotrans also suddenly entered the express market, and its biggest advantage is its logistics background of more than 50 years and its perfect network.

The second are international express giants. Four giants in the global express delivery industry -- DHL, Federal Express, United Parcel Service (UPS) and TNT have entered China. In addition, Sagawa Express and Poly established a joint venture company in 2004.For these enterprises, rich experiences, abundant funds and global network will enhance their competitive strength to a great extent.

The third force comes from the large and mediumsized private express enterprises. Some private express companies have grown up after nearly ten years of development. The most famous among them are Datian Express, SF express, ST Express, etc. These companies passed the stage of primitive accumulation each with an asset over 100 million yuan. This kind of enterprises generally has a strong advantage in a certain region, and it make further nationwide business based on this advantage. The following are the accounting rates of three forces in the domestic express market, as shown in the following figure.

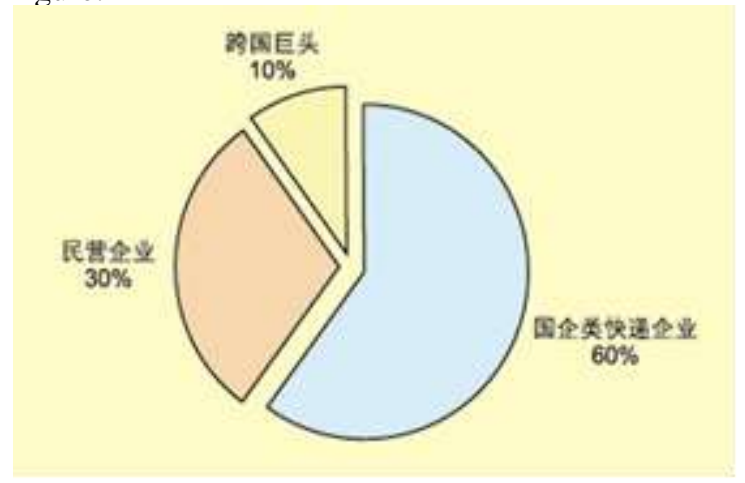

Figure 1. Transnational Giants

\section{B. Analysis of Factors Influencing Customers' Choice of} Express

\section{1) Service Level}

In management of each section in express service, careful organization and close cohesion are lacked and the management still stays at the extensive management stage, which causes disjunction between some sectors and departments and affects the express speed. In addition, the technology management means of domestic enterprises are behind developed countries. Although in recent years a network query system has been established, the monitoring degree of mail is still relatively poor. Many problems such as lost mails, mistaken delivery and untimely reply to query caused customer dissatisfaction and seriously affected the quality of service.

The following is statistical analysis on the express complaint by 315 complaint net in 2009 (as shown in the following figure).

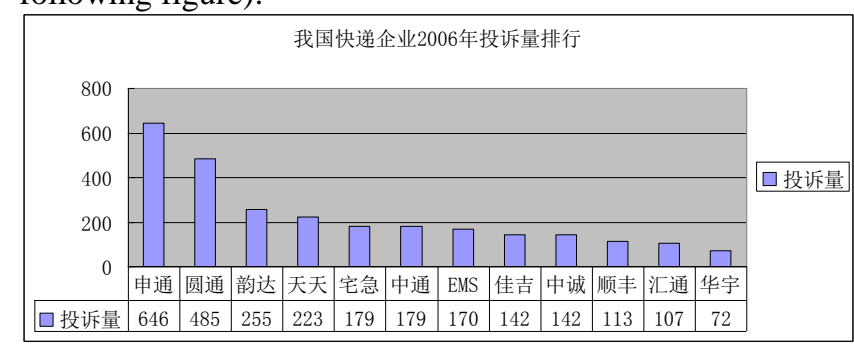

Figure 2. List of Complaint Quantity toward Express Companies in China in 2006

\section{Complaint quantity}

Shentong Yuangtong Yunda TNT

Zhaiji Zhongtong Jiaji Zhongtong

Shunfeng Huitong Huayu

Complaint Quantity

According to the result of the survey, the quantity of complaints toward express companies in China is very large, and the service level is to be improved. SF, Huitong and Huayu have the smallest complaint quantity and their service levels are relatively high among private express enterprises However, in the comparative analysis of the indicators, many factors including service quantities in different enterprise years and complaint convenience should be considered. In this way, comparability can be realized. Therefore, further research will be on adjustment of the index combining with other factors.

At the same time, survey made by 315 Complaint Net also displays that the three main aspects of complaining are display, goods loss and damage. They have become the three difficulties blocking express enterprises. Reasons for the above phenomenon mainly lies in the follows, on the one hand, staff in express enterprises have low quality and they did put customers at first; on the other hand, the majority of enterprises adopt special permitting joining ways to expand the express network. The management efficiency is very low and the coordination between the franchisee is difficult. To some extent, this results in the loss or delay of customer service.

2) Time Effect Level

The system has not been completely trimmed. At present, there are still many aspects displaying some features of planned economy, such as the speed unified by the nation, lacking flexible system mechanics, disability to 
make adjustment according to market; use of administrative means in the management, the mandatory plans, rigid system, promotion according to status and inflexible employment system. The enterprise does not have a set of effective supervising and incentive mechanism, and it cannot practically stimulate the staff's enthusiasm for work.

The following is the telephone survey of express business, and the content of investigation involves operator's attitude, commitment of delivery time, commitment of pick-up time and pricing level. The results are shown in the following table.

If only commitment of delivery time and pick-up time are considered, the express enterprises listed above have no obvious difference between each other. The time effectiveness of SF may be the best. Further research should put the proportion of the times of delayed goods delivery into the checking range.

\section{3) Price Level}

The telephone survey results in the table show that there are differences in the price levels of express enterprises listed. SF, Shentong and Quanyi have the highest prices, and Huitong, Zhongtong, Qincheng, and Yunda have relatively low prices. The price levels doe not mean enterprise's competitiveness. Service levels (performance-price ratio) should be considered. According to a survey by Oriental (International) Market Research Company, the five important factors for residents to choose express delivery companies are delivery time, timely delivery, adaption to different business needs, good reputation, reasonable prices. The price factor is put in the fifth place.

Fierce competition among express enterprises mainly lies in competition in the aspect of service level. Through the telephone survey conducted by express enterprises, SF and Zhaijisong respectively opened a unified national customer service hotline, which can provide many items of service such as ordering, cargo tracking, business consultation, complaints and suggestions and realizes respect for their customers and customers at top status. The other surveyed express enterprises have no unified customer service phone, and their business is in the charge of each chain store, which can hardly ensure high customer service levels. It is also found that due to the special permitted joining management mode, each site is relatively independent and is only responsible for business within an area. For example, in a survey of Yuantong, the writer intentionally called the Dongpu chain store and found that the attitude of the operator is not good. The service mode of Yuantong will undoubtedly bring certain negative effects on its competitiveness.

Improvement of the service level should start from improving the service provided by the customer service centers and customer service staff members. Secondly, improvement of the quality of the express staff members should be made. Express staff members directly touch customers on behalf of express enterprises, and their words and behaviors stands for the image of express enterprises. At present, the express staff members in many express enterprises have low quality. The company lacks unified training and management so that the service attitude of some express staff members is very bad. This caused extremely dissatisfaction and this will undoubtedly make the enterprise service reputation worse and worse. Poor reputation and service will not only cause complaints but also lose customers and market. Therefore, how to make good education and training of employees has become one of the key issues for private express enterprises.

\section{Analysis of International Express Enterprises' Development in China and Successful Experiences}

\section{FedEx Company}

Federal Express was founded in 1970s. In 1984, FedEx entered China. At that time, due to policy restrictions, foreign express enterprises must choose to cooperate with Sinotrans under the Ministry of Foreign Trade for obtainment of qualifications to start international express business in China. In this context, Federal Express chose to have partial agent cooperation with Sinotrans. In 1996, FedEx won approval from China Civil Aviation to operate the cargo lines to and fro central America, and become the first American All Cargo Transportation Aviation Company to and fro central America. In the same year when the contract with Sinotrans expired, contract expires, FedEx to cooperate with Datong Group with more than 30 branches and radiation to hundreds of cities in China. In 2006, America FedEx and DTW signed an agreement in which the front purchased $50 \%$ of the shares of DTW and the 89-cities express business network of DTW in China with $\$ 400$ million.

Successful Experiences of Federal Express

The first is introduction of international difference express services. In Asia and Pacific region, small and medium size enterprises account for $98 \%$ of the total. These enterprises need to deliver packages at more preferential prices in many cases, and they have no high requirement on time. In order to compete in this part of the market, FedEx launched international economic express business in the Asia and Pacific Region in early 2008.The service is design to deliver single packages which respectively are not exceeding $68 \mathrm{~kg}$ at non-emergency status, and to deliver more pieces of goods with total weight unrestricted. Compared with the existing FedEx international prior service, the international economic express service usually has delivery time over two days but its prices are about $20 \%$ lower.

Since 2002, Federal Express and Kodak Company formed a strategic partnership to establish Federal Express "self-service counters" in the Kodak stores, and customers can reach the designated Kodak stores to send international express articles through FedEx. In addition, FedEx also established the offices of office work and document printing company, and established many stores to increase the express service spots for continuously extending its business.

The second is large operation network. FedEx Corp has nearly 700 cargo transportation planes. They can take off and land at 365 airports in the world with its service throughout more than 220 countries and regions in the world. In the world, it has 70,000 transportation vehicles, 4,300 delivery points and more than 1,200 Service Centers. What is more, it has an express network with 260,000 employees covering the regions accounting for over $90 \%$ of GDP. On the Chinese market, the Federal Express service network has covered more than 220 cities. The ground vehicles, professional delivery staff members, large 
air network, and the global operation monitoring system of FedEx is the main material guarantee to provide good Express and on-time service.

Wide application of information technology uses information means in communication with customers. Sorting, information storage and tracking of goods greatly improves the work efficiency and market competitiveness of FedEx Corp. FedEx set up a customer service and management operating system to tracking the location of packages in transport. In this way, customers can understand delivery of goods in the global range. In 1994, Federal Express established its company web site, through which its customers can track delivery on the internet. At present, Fedex's consignment procedure software has many versions, which greatly support its customers.

Continuously improvement of customer service level, establishment of an evaluation system and a performance evaluation system and constant seeking of the best way to improve work are the basic approaches of Fedex to improve its customer service level. The company continues to seek the views from its customers, to carry on questionnaire surveys, and to develop different grades of products to meet the different needs of its customers.

The important is attention to training of talents. Federal Express pays attention to personnel training, and each year it provides special funds to do this work. It encourages its staff members to continue their education in order to make its staff understand the operation of the entire company. The company implements a job rotation system, creating a comprehensive development and learning opportunity to each employee, It also sends its staff to Hong Kong and USA for learning and training to expand their vision and to accept advanced ideas in science and technology.

\section{MEASURES TO DEVELOP CHINESE EXPRESS INDUSTRY}

\section{A. Large Express Enterprise Merging and E-Business Cooperation}

1) Modes of Large Express Enterprise Merging and Acquisition

Through the merging and acquisition in the area are three modes, namely, horizontal merger, vertical merger and mixed acquisition At present, China's express industry is in the growth stage, the market demand is further enlarged, and the industry is in prosperity. However, the competition is more fierce. To improve the market share, the horizontal merger and acquisition of enterprises further expanded. Each line of capitals inflow, and domestic and foreign enterprises make horizontal merger and acquisition, which displays a "purchase storm". At the same time, a few private express enterprises with strategic eyesight are aware that the competition changes from single enterprise competition to supply-chain competition. On market, there are a minority of longitudinal merging and acquisition modes. Because the industry has huge market potential, some venture capital and privately collected funds also entered the express industry for mixed acquisition and most companies still stay at the market exploration stage. In overall, the express-industry merger and acquisition are mainly horizontal merger and acquisition. There is a little of vertical merger and acquisition and little mixed merger and acquisition. Each enterprise can combine their own actual situations to select the suitable model of acquisition.

\section{2) Related Strategies in Merger and Acquisition}

a) Multiple-Ways Financing: The express industry is an industry with a lot of capital, no matter the pre-stage merger and acquisition and later-stage operation. Foreign express giants expand and improve service with millions of dollars. In contrast, the more outstanding is the urgency of financing for large Chinese express enterprises. Enterprises financing channels include internal source financing and external source financing. The front takes internal source accumulation as the main work but most of this cannot meet the demand of large-scale merger and acquisition. The latter includes equity financing, bank loans and other ways. But recently the two kinds of crediting modes of domestic banks are not suitable for express enterprises because the main value of express enterprises are about their brand and networks. Their operating facilities are mainly lease. This is not attractive for banks that pay attention to collaterals and enterprise scales. 所以 Although the threshold is high and to obtain improvement is very difficult, to narrow the funding gap, private enterprises can still consider many financing channels such as listing, privately collection and risk investment.

b) Seeking of Policy Support:Interest groups including industry associations can be employed to lobby the government and to influence the establishment of relevant policies. According to the current economic situation, to realize the traditional express service upgrading and consumers' diversified postage demand, relying on only the state-owned express is not enough and a competitive mechanism should be introduced in the express delivery market. In this way, on the one hand this can make the state-owned post enterprises more dynamic to provide better basic postal service; on the other hand, this can prevent foreign companies from monopolizing on some divided markets and ensure national economy and national security. The multiple competition pattern of the posting industry in China has been formed. Although it is not very standardized, the condition of development cannot be blocked. The state should determine the list of enterprises to support, and centralize resources to support the enterprise merger and acquisition, which has better control force and execution force to have standardizing industrial order and stabilizing competitive force.

c) Cooperation with e-commerce enterprises at the layer of electronic supply chains. Due to the huge market brought by e-commerce, each express company pays great attention to cooperation with electronic commerce enterprises. But in the process of cooperation, each enterprise must specify business orientation to reach winwin in the layer of supply chains between two parties. As social logistics, the express industry cannot fix itself to a single shopping platform to become enterprise logistics for a single period economic status in cooperation with the electronic commerce enterprises. Or its development would be blocked. 
At present, Alibaba shares Xingchen Express with the intention to professional e-commerce logistics; Jingdong Mall also established warehousing centers in many large cities such as Beijing and Shanghai and made its logistics strategies. The several e-commerce companies established their own logistics, which shows their determination to extend their supply chains. This also directly illustrates their urgency of improving the express service quality. But the action by the enterprises are mostly behaviors that they have to do, and most small and medium electronic commerce enterprises do not have the force to set up their own logistics. So, to improve the level of express service is realization of the win-win benefits between both parties.

Express enterprises can unite with e-commerce enterprises to form strategic alliances to make cooperation in the layer of supply chains. Express enterprises can use the mature information system and management modes of e-commerce enterprises to promote their improvement of their own strength. Electronic commerce enterprises ensure the priority and time requirements on express enterprises in the aspect of enterprise storage and distribution.

d) There are proper conditions, development of own electronic commerce should be made. Express enterprises can enter the field of electronic commerce from the section of logistics and distribution, run their own websites by themselves and extend to the upper end of supply chains for increasing the volume of the goods and improving the profiting. For example. Beijing ZJS express launched article agent-selling platform named as E Buying Express Delivery". SF EXPRESS launched a shopping website "SF E Business Circle", STO launched the "Jiujiu Ticketing Network" to sell train tickets online, etc, which open a new mind for express companies to use their own resources.

\section{B. Improvement of Express Industry Infrastructure}

\section{1) Promotion of Informationization}

Enterprises must be based on technology and complete consideration of logistics technology application when they are making express informationizaiton construction, to enhance the core competitiveness of enterprises and to obtain the initiatives for development of enterprises. For example, through application of bar code technology, logistics identification RF technology, electronic data exchange technology, global positioning system, geographic information system etc., realization of automatic identification of goods, sorting, loading, unloading, storage and obtainment can be realized for improvement of efficiency of logistics operation.

2) Accelerating of Investment and Construction of Express Infrastructure

Investment and construction of infrastructure is the important content of express industry planning in China. Therefore, great investment should be put into construction of ports and ship teams. Some construction investment of the industry infrastructure in the express industry construction is very great. The investment includes purchase and construction of ships, cargo planes, container yards, goods station, railways, highways and pipelines should learn from practice by foreign the government to set up private business promoted by the government".

3) Reduction of Delivery Cost
Through the delivery of efficiency, cost is reduced Enterprises should realize distribution of efficiency, reduce the times of transport, improve loading rate and properly arrange vehicle plans. They should also choose the best means of transportation for reduction of distribution costs. Cost is controlled and reduced with the modern information management system. with the traditional manual management mode, enterprise cost control is influenced by many factors, and optimal control can hardly be realized at each section. On the one hand, enterprises to use information system can make various logistics operations or business can be handled accurately, on the other hand, through the information system of data collection, forecasting analysis can be made to control the possibility of logistics costs. Enterprise staff's awareness of cost management should be paid attention to. The work to reduce costs should be expanded from the logistics management departments to each department of an enterprise. Logistics cost management should be made from the whole cycle of development, production and sales to make the employees of the enterprises have the strategic cost consciousness for long-term development.

\section{Improvement of Comprehensive Service Level}

\section{1) Understanding of Customer's Needs}

Increased competition, changing customer requirements and pressure to continuously improve quality mean that customer demand changes constantly and the express industry must anticipate these changes and make a positive response for constantly changing business objectives. With the change in demand, the express process must adapt to this change in order to maintain customer satisfaction.

When establishing an item of express service with customer-orientation, the distribution staff members must understand the needs and expectations of customers for delivery. Different customers have different needs and expectations. For example, customer requirements for each part of the distribution may include timely and reliable delivery, good communication, timely delivery, highfrequency delivery, Order status information availability, efficient feedback process, emergency situation treatment, goods completion rate, accurate and timely billing, advisory answers, etc.

The process to define the customers' demand is very complex, and logistics service providers must learn to understand and to pay attention to customer needs. The following 3 steps can be used to determine customers' needs,

a) Understanding of Customers' Business, Purchasers and Users;

To provide value is to provide products and services. Express service providers must understand the business of the customers, When the customer requirements are changed into the business standard of the company, the matter is much easier. To understand the diversification of orders is a good example. This requirement is also different due to types of products, and specific different treatment must be made. Identification of customers' requirements and provision of corresponding service can increase customer satisfaction and may reduce cost.

In most large companies, the purchase department is not the end user, so there may be a different satisfactory 
standard. If the purchase department as part of the production company (i.e. the purchasing department), it may be affected by the other departments, Like production, quality control, logistics, product development and finance, the buyer may care more about prices and delivery periods, while other sectors may be more interested in quality. Users (product lines) may feel that the effects of the product and the property are more important. Understanding the different roles played by the purchasing departments and customers in the purchase process is helpful for suppliers to identify needs and meet their expectations.

\section{b) Identifying Customer Needs and Expectations}

The express service providers must discuss with their customers on which service has key characteristics and put forward some qualitative and open problems to customers. The flexibility is to express their needs. From the suppliers' point of view, a list of demands can be given to the customers. Directly ask customers and listen to the customers' statements. This is the right way to know what the customers think and need. From the customer statement perspective, many customers tell their suppliers about the minimum requirements. These statements are usually very clear. Although the information is very necessary on business, it may merely indicate some basic questions, namely, the minimum customer expectations. Once you understand the minimum requirements, further discussion with customers should be established on the basis. We should also help suppliers to understand customers' expectations on value-added service. In addition to the existing customers' statement, the previous business reports are also the potential source for customers to feedback information.

c) The change of needs and expectations in discussion with customers and determination of payment service desire

Once the minimum requirements and expectations of customers are clear, the suppliers should explore the relative importance of each project. They can discuss with their customers on whom behavior is important, unchanged and what is the cause. $。$ This information will help distinguish the customers' demand and value-added services. If you provide value-added service and the basic needs are not met, customer satisfaction cannot be reached. Another is to discuss the customers' views on the current level of service. It provides the standard on which service is beneficial to competitive advantage. It is unfeasible that the customers are willing to pay the prices and all customers' needs are met. Therefore, it is very important to understand which kind of service is at the minimum requirement and which kind of service beyond expectation is very important. To provide value-added service needs spending of money and the customers will buy only what they think as the valuable service. The suppliers should discuss with the customers on what they are willing to pay. When they realize that the expenses for providing service, some customers may reevaluate the importance of this service.

\section{2) Evaluation of Present Service and Ability}

Once you understand the customer's idea, logistics service providers must find out their current service ability and the difference from the actual requirements. This includes what steps to take to meet the special service objectives and to identify service provided by the competitors. This helps to determine which service is in the expectation by each manufacturer. If EDI is an item of value-added service and it is provided by a provided, the company will have a competitive advantage.

3) Interpretation of Current Practices and Gap from customers' Requirement

Once the supplier understands customers' needs is different from the provider, the gap between the two can be analyzed. Many companies think that the gap between the customers' demand and the service they provide is very small. After investigation, they often find that they have misinterpreted the customers' demand.

When asked about the needs and expectations, a consumer of an article company said that timely delivery and none-loss delivery are the two most important criteria to evaluate distribution service. When the contrasting between the provided service and the customers' demand is checked by the company, the company would timely find the gap in the aspect of delivery, but it cannot find the gap in the aspect of non-loss delivery. The company also pays attention to these aspects of competition evaluation, It is realized that customers have shown the quality, timely and non-loss service after high quality work. With this information, the consumer company determines that it is very important to eliminate the gap in the aspect of timely delivery. When the quality of none-loss delivery surpasses expectations of customers, new competitive advantage would come.

The elimination of certain interest gaps includes improvement of service levels. But there is a way of regular investigation in the improvement process in order to understand evaluation of customer satisfaction. Other benefits may include increased income, customer loyalty and competitive advantage. One of the interests is to avoid loss of business due to poor quality of service. On the basis of the analysis, the company must determine to make its benefits exceed costs. Of course, these standards are different from customers or market division, and detailed analysis should be made in each specific case.

4) Specific Service to Meet Customers' Special Needs

When the service providers ask the customers what is the most important and analyze results, it is obvious that different customers need different items of service and service standards. In order to make as many as possible customers satisfied, the company should make classification of its customers according to similarity of expectations. Many companies in the industry classify their customers according to industries, product types, investigation of these customers naturally classified, suppliers can provide better service.

\section{CONCLUSION}

With rapid development of the internet, the number of users and size of transactions on the e-commerce market in China has had the ability to rely on their own need to promote the industry. At present, there are many large websites including taobao.com, Paipai net and Yiqu. Due to the initial investment and the sales cost for expansion for the e-commerce are high, and subject to the definition of the rules by leaders, the internet cannot profit within a short period. This obviously makes the Chinese electric 
commerce industry have barriers. A monopolization pattern happens and it is a new challenge to development of the express industry.

\section{REFERENCES}

[1] Fan Qiurong, Express Industry Prospect in China and Measures in E-Commerce Environment, [J]Shanghai Logistics, 2006

[2] Wen Xiaoqing, Ren Zhongxiang, edited by Zhang Li, Consumer psychology, Tianjin University Press, 2005.

[3] Bhatnagar A, Misra S, Rao H R. Online risk, convenience, and Internet shopping behavior. Tsinghua University Press

[4] Dua Ling, Zhu Xiuwen. The Third Party Logistics Customer Satisfaction Measurement [J]. Logistics technology .2005 (3) :1215

[5] Du Jiang, Modern Express in E-commerce and Measures [J] Harbin Business University Journal, 2005

[6] Kong Lingting, Development of E-commerce Express in China, [M] Chinese Market, 20073
[7] Journal Paper, Wang Xicheng, Strategic Business for Express Enterprises under Electronic Commerce Environment

[8] Ding Yuanzu, Discussion on Development of Express Enterprises in Electronic Commerce Environment, 10th periodical, 2009, CNKI

[9] Zhang Duo and Zhou Jianqin, chief editors, Electronic Commerce and Logistics Management, Higher Education Press, 2005

[10] Dong Yan. Measures on Development of Chinese Private Express Enterprises [J]. Chinese Logistics and Procurement, 2009, (21)

[11] $\mathrm{Xu}$ Yong, Analysis on Current Situation and Development Trend of Chinese Private Express [M]. Shanghai University Press, 2006:9

[12] Wang Mingzhi, editor in chief, Logistics Management Case and Training, Mechanical Industry Press, 2010

[13] Wang Qun, Han Xiang, Xiao Yu: Express Management with Enterprise Electronic Commerce [M], Science Press

\begin{tabular}{|c|c|c|c|c|}
\hline $\begin{array}{l}\text { Express } \\
\text { enterprises }\end{array}$ & $\begin{array}{l}\text { Operator's } \\
\text { attitude }\end{array}$ & $\begin{array}{l}\text { Promise of delivery } \\
\text { time }\end{array}$ & Pick-up time & Pricing level \\
\hline SF & Very good & $\begin{array}{l}\text { Morning sending to } \\
\text { afternoon receiving, } \\
\text { and afternoon sending } \\
\text { to delivery in the next } \\
\text { morning }\end{array}$ & $\begin{array}{l}\text { The fastest is } 1 \\
\text { hour, and no longer } \\
\text { than } 2 \text { hours }\end{array}$ & $\begin{array}{l}\text { The first weight } \\
10 / \mathrm{kg} \text {, added } 1 \\
\text { yuan } / \mathrm{kg}\end{array}$ \\
\hline ZJS Express & Very good & $\begin{array}{l}\text { Morning sending to } \\
\text { afternoon receiving, } \\
\text { and afternoon sending } \\
\text { to delivery in the next } \\
\text { morning }\end{array}$ & Within 2 hours & $\begin{array}{l}8 \text { yuan within } 1 \\
\mathrm{~kg} \text { and } 9 \text { yuan } \\
\text { within } 2 \text { kilos }\end{array}$ \\
\hline STO & Common & The next day arrival & Within 2 hours & $\begin{array}{l}/ \mathrm{kg} \text { The first } \\
\text { weight } 10 \\
\text { yuan } / \mathrm{kg}, \text { added } \\
1 \text { yuan } / \mathrm{kg}\end{array}$ \\
\hline $\begin{array}{l}\text { Yunda } \\
\text { Express }\end{array}$ & Common & Arrival the next day & Within 2 hours & $\begin{array}{l}\text { The first weight } \\
8 \text { yuan } / \mathrm{kg}, \\
\text { continued } \\
\text { weight } \mathrm{O} .5 \\
\text { yuan } / \mathrm{kg}\end{array}$ \\
\hline 天天 TNT & Common & Arrival the next day & Within 2 hours & $\begin{array}{l}\text { The first weight } \\
10 \text { yuan } / 0.5 \mathrm{~kg} \text {, } \\
\text { added } 1 \text { yuan } \\
/ 0.5 \mathrm{~kg}\end{array}$ \\
\hline Zhongtong & Common & $\begin{array}{l}\text { Morning sending to } \\
\text { afternoon receiving, } \\
\text { and afternoon sending } \\
\text { to delivery in the next } \\
\text { morning }\end{array}$ & Within 2 hours & $\begin{array}{l}8 \text { yuan within } 3 \\
\mathrm{~kg} \text {, added } 2 \\
\text { yuan } / \mathrm{kg}\end{array}$ \\
\hline $\begin{array}{l}\text { Huitong } \\
\text { Express }\end{array}$ & Not very good & $\begin{array}{l}\text { Morning sending to } \\
\text { afternoon receiving, } \\
\text { and afternoon sending } \\
\text { to delivery in the next } \\
\text { morning }\end{array}$ & Within 2 hours & $\begin{array}{l}\text { The first heavy } \\
7 \text { yuan } / \mathrm{kg}, \\
\text { continued } \\
\text { weight } 1 \text { yuan } \\
\text { /kg }\end{array}$ \\
\hline
\end{tabular}




\begin{tabular}{|l|l|l|l|l|} 
(DDS) & No answering & $\begin{array}{l}\text { Morning sending to } \\
\text { afternoon receiving, } \\
\text { and afternoon sending } \\
\text { to delivery in the next } \\
\text { morning }\end{array}$ & Within 2 hours & $\begin{array}{l}8 \text { yuan } / 2 \mathrm{~kg}, \\
\text { added 1 yuan } \\
/ \mathrm{kg}\end{array}$ \\
\hline $\begin{array}{l}\text { Express a } \\
\text { whole }\end{array}$ & Good & $\begin{array}{l}\text { Morning sending to } \\
\text { afternoon receiving, } \\
\text { and afternoon sending } \\
\text { to delivery in the next } \\
\text { morning }\end{array}$ & Within 2 hours & $\begin{array}{l}\text { The first weight } \\
10 / \mathrm{kg}, \text { added 1 } \\
\text { yuan } / \mathrm{kg}\end{array}$ \\
\hline
\end{tabular}

